Hydrology and Earth System Sciences, 6(3), 551-557 (2002) C EGS

\title{
Nitrogen circulation in a Mediterranean holm oak forest, La Castanya, Montseny, northeastern Spain
}

\author{
Anna Avila, Anselm Rodrigo and Ferran Rodà
}

CREAF, Univertistat Autònoma de Barcelon, 08193 Bellaterra, Spain

Email for corresponding author: Anna.avila@uab.es

\begin{abstract}
Bulk deposition, wet-only deposition, throughfall and dry deposition inferred from washing foliage and surrogate surfaces were used to describe inorganic $\mathrm{N}$ inputs to a forested catchment in the Montseny Mountains (La Castanya, Catalonia, Spain). Bulk inputs of inorganic N were moderate, with a mean of $5.7 \mathrm{~kg} \mathrm{~N} \mathrm{ha}^{-1} \mathrm{yr}^{-1}$, ranging between 4 and $10 \mathrm{~kg} \mathrm{~N} \mathrm{ha}^{-1} \mathrm{yr}^{-1}$ for the period 1983 to 2000. Dry deposition fluxes estimated from washing branches added about $9 \mathrm{~kg} \mathrm{~N} \mathrm{ha}^{-1} \mathrm{yr}^{-1}$ to wet inputs and the total atmospheric deposition was estimated in $15 \mathrm{~kg} \mathrm{~N}$ $\mathrm{ha}^{-1} \mathrm{yr}^{-1}$. Despite this substantial input flux, nearly all the inorganic nitrogen was retained within the forest ecosystem: $\mathrm{NH}_{4}^{+}$and $\mathrm{NO}_{3}^{-}$ concentrations decreased dramatically as water crossed the canopy and the soil profile. In the stream, at baseflow conditions, $\mathrm{NH}_{4}^{+}$and $\mathrm{NO}_{3}^{-}$

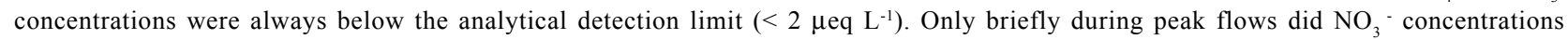
increase up to $100 \mu \mathrm{eq} \mathrm{L} \mathrm{L}^{-1}$. Averaged over 10 years (1984-1994), the export of $\mathrm{N}$ at the catchment outlet was $0.05 \mathrm{~kg} \mathrm{~N}^{-1} \mathrm{yr}^{-1}$. This indicates a very tight $\mathrm{N}$ cycling allowing for an increase of $\mathrm{N}$ availability in these undisturbed forest ecosystems.
\end{abstract}

Keywords: bulk deposition, throughfall, dry deposition, soil water, nitrate, ammonium, Spain, Montseny, La Castanya

\section{Introduction}

Aggrading forests receiving moderate $\mathrm{N}$ inputs retain most of the deposited $\mathrm{N}$ within the ecosystem, with only a minor fraction being lost to streams (Vitousek, 1977). However, in recent years the deposition of nitrogen has increased in many regions of Europe and North America because of enhanced agricultural and industrial activities (Galloway 1995; Vitousek et al., 1997). The combined effect of high $\mathrm{N}$ inputs and high nitrification (which depends on site specific characteristics, such as soil depth, soil temperature, soil moisture, and high $\mathrm{pH}$ ) may lead to nitrogen saturation in terrestrial ecosystems (Aber et al., 1989, 1998; Agren and Bosatta, 1988; Nihlgard, 1985). Nitrogen saturation has been found for forests receiving large loads of $\mathrm{N}$, in the range $20-100 \mathrm{~kg} \mathrm{~N} \mathrm{ha}^{-1} \mathrm{yr}^{-1}$. In particular, these elevated inputs have been described for the Netherlands (Van Breemen et al., 1987; Wyears et al., 1992), Great Britain (Emmet et al., 1993), Scandinavia (Andersen et al., 1993) and the United States (Aber et al., 1989, 1998; Bytnerowicz and Fenn, 1996; Fenn et al., 1996). A symptom of $\mathrm{N}$ saturation in forests is the increase of $\mathrm{NO}_{3}^{-}$leached to the streams.

In Spain, increasing $\mathrm{N}$ emissions have occurred because of recently increased fossil fuel consumption and enhanced livestock production: from 1983 to $1998, \mathrm{NO}_{\mathrm{x}}$ emissions increased by $17 \%$ and $\mathrm{NH}_{3}$ emissions increased by $31 \%$ (EMEP, 2000). Nitrate concentrations in rainwater also increased significantly during this period although the trend was statistically non-significant when considering $\mathrm{NO}_{3}^{-}-\mathrm{N}$ deposition due to lower rainfall in later years (Avila and Rodà, 2002).

In this paper, the results obtained since 1983 for a study of a holm oak forested catchment of La Castanya, Montseny Mountains (Catalonia) are used to:

(1) describe the inorganic $\mathrm{N}$ deposition rates (wet and dry).

(2) describe the changes occurring in $\mathrm{NO}_{3}{ }^{-}$and $\mathrm{NH}_{4}^{+}$ concentrations as water moves through the ecosystem.

(3) discuss the effects of the atmospheric inputs on the $\mathrm{N}$ cycle in these holm oak forests. 


\section{Study site}

The Montseny Mountains ( $41^{\circ} 46^{\prime} \mathrm{N}, 2^{\circ} 21^{\prime} \mathrm{E}$; $40 \mathrm{~km} \mathrm{NNE}$ from Barcelona) cover an area of about $400 \mathrm{~km}^{2}$, and reach their highest altitude at 1707 m.a.s.l. They are mostly forested (holm oak, pines and beech), with heathlands and grasslands in the upper parts and arable crops in the lower reaches. The bedrock consists mostly of metamorphic phyllites and schists. The climate is montane Mediterranean. Mean annual precipitation was $901 \mathrm{~mm} \mathrm{yr}^{-1}$ and ranged between 640 and $1660 \mathrm{~mm} \mathrm{yr}^{-1}$ in the period August 1983July 2000 (hydrological years being defined from 1 August to 31 July). Mean annual temperature ranged from 10 to $14^{\circ} \mathrm{C}$.

The sampling site, named La Castanya, was at La Castanya valley (altitude 700 m.a.s.l.), amidst extensive holm oak forests in the Montseny massif. The main topographic characteristics and the stand structure of this forest are summarised in Table 1. A station for air pollution monitoring from the Departament de Medi Ambient de la Generalitat de Catalunya was used to compare bulk and wet collecting methods. This station (named PA) is at the foot of the Montseny Mountains, at a linear distance of $6 \mathrm{~km}$ from La Castanya in the surroundings of the town of Santa Maria de Palautodera (200 m.a.s.1, 5000 inhabitants).

Table 1. Site characteristics (mean $\pm \mathrm{SE}, \mathrm{n}=4$ ) of La Castanya holm oak at Montseny. Stand and tree data are for stems having a diameter at breast height $>5 \mathrm{~cm}$.

\section{Variable}

\begin{tabular}{ll}
\hline Altitude $(\mathrm{m})$ & $731 \pm 4.3$ \\
Slope $\left(^{\circ}\right)$ & $37.5 \pm 0.6$ \\
Stand density $\left(\right.$ stems ha $\left.^{1}\right)$ & $2127 \pm 16.2$ \\
Basal area $\left(\mathrm{m}^{2} \mathrm{ha}^{1}\right)$ & $26.4 \pm 2.0$ \\
Tree height $(\mathrm{m})$ & $5.9 \pm 0.3$ \\
Canopy depth (m) & $3.1 \pm 0.2$ \\
Tree cover $(\%)$ & $128 \pm 0.2$ \\
\hline
\end{tabular}

\section{Material and methods}

At La Castanya, bulk deposition was sampled in the holm oak forest in a clearing of sufficient diameter to avoid interference by surrounding trees. Bulk deposition was collected weekly from four (until 1993) and two (from 1993 to 2000) replicate bulk collectors consisting of a polyethylene funnel connected by tygon tubing to a 10-1 polyethylene bottle. At PA, precipitation was collected weekly with two bulk collectors and one wet-only collector (MCV trademark).

Throughfall was sampled weekly in four replicate plots inside the holm oak forest of La Castanya. Throughfall plots were at a distance of 100-200 $\mathrm{m}$ from the bulk deposition clearing. The plots were circular, of 7-m radius. Each plot contained eight throughfall collectors, consisting of a 10$\mathrm{cm}$ diameter funnel connected to a 2-1 polyethylene bottle. The sampling bottles, both for throughfall and bulk deposition, were kept in the dark to minimise biological transformations of the sample. Stemflow was also sampled using rings around the tree stems, with ten trees sampled in one of the plots (Rodrigo, 1998). As stemflow $\mathrm{N}$ fluxes were very low compared to throughfall, these results are not discussed here.

Dry deposition rates were calculated from an experiment of parallel branch- and plate-washings during rainless periods. Eight extruding branches were chosen and six metacrylate plates of $20 \times 20 \mathrm{~cm}$ and $0.2 \mathrm{~cm}$ thickness were placed at the top of dominant trees near the throughfall plots. On five rain-free periods both these branches and plates were washed in situ with distilled deionised water after exposure times ranging between 72 to $187 \mathrm{~h}$ since the last rainfall, and dry deposition fluxes per unit leaf or plate area $\left(\mu \mathrm{g} \mathrm{cm}^{-2} \mathrm{~h}^{-1}\right)$ for $\mathrm{NO}_{3}^{-}-\mathrm{N}$ and $\mathrm{NH}_{4}^{+}-\mathrm{N}$ were calculated. The resulting values were then extrapolated to estimate dry deposition fluxes to the canopy at annual scale, assuming a leaf area index (LAI) of five for the La Castanya holm oak site (Sabaté et al., 1999).

At La Castanya, the movement of dissolved $\mathrm{NO}_{3}{ }^{-}$and $\mathrm{NH}_{4}^{+}$through the soil profile was studied in a 3-m long trench, with two zero tension through-flow collectors installed at different depths to collect: (1) the forest floor solution (0-5 cm-depth), and (2) the deep flow at the bedrock contact (160 cm-depth). In addition, the soil solution was sampled with ceramic-cup tension lysimeters evacuated at $-65 \mathrm{kPa}$. Eight lysimeters were used, four at each depth (20 $\mathrm{cm}$ and $40 \mathrm{~cm}$ depth; Avila et al., 1995).

Streamwater samples were collected manually weekly, but more frequent sampling was programmed during stormflows using an automatic collector (Manning S-4040). Sampling frequency was at fixed time intervals, with the frequency adjusted to cover the whole hydrograph.

Study periods differed among sites and among the processes studied. The longest record was for rainwater chemistry, for which 17 years of data were available (August 1983 to July 2000). Throughfall data were collected from 6 June 1995 to 25 June 1996. The washing experiment of branches and plates was conducted on May-June 1996. Streamwater chemistry and discharge measurements from the stream (named TM9) that flows through a 5.9 ha 
catchment within the holm oak forest extended from August 1983 to July 1994. Storm events were sampled from August 1983 until July 1988. Lysimeters were emptied weekly from November 1983 to June 1986. Through-flow solutions from the trench were collected weekly from May 1985 to May 1888.

All water samples (bulk deposition, wet deposition, throughfall, leaf and plate washes, soil solution and streamwater) were taken to the laboratory on the day of sampling, where $\mathrm{pH}$, conductivity and alkalinity were analysed within 24-48h. Samples were then filtered with $0.45-\mu \mathrm{m}$ Millipore filters, and the filtrate was deep-frozen for later analyses of major anions $\left(\mathrm{SO}_{4}{ }^{2-}, \mathrm{NO}_{3}{ }^{-}\right.$and $\left.\mathrm{Cl}^{-}\right)$and cations $\left(\mathrm{Na}^{+}, \mathrm{K}^{+}, \mathrm{Ca}^{2+}, \mathrm{Mg}^{2+}, \mathrm{NH}_{4}^{+}\right)$. Nitrate was analysed by ion chromatography and $\mathrm{NH}_{4}^{+}$by flow injection analysis until 1996 and by ion chromatography thereafter. All ion analyses included synthetic samples of known concentrations within the runs to check for replicability and accuracy. Data were further screened for analytical quality by the ratios sum of cations / sum of anions (on an equivalent basis) and calculated conductivity / measured conductivity. Since 1991, the laboratory participated in a joint laboratory intercomparison of analytical results coordinated by ISPRA (AQUACON Project, Mosello et al., 1998), with very satisfactory results.

\section{Results and discussion}

\section{WET AND DRY DEPOSITION}

Mean rainwater composition at La Castanya was not acidic: the volume-weighted mean (VWM) alkalinity for the period 1983-2000 was $14.3 \mu \mathrm{eq}^{1^{-1}}$. Calcium (VWM concentration $\left.=52.5 \mu \mathrm{eq} \mathrm{l}^{-1}\right)$ was the main cation counterpart to acidic anions (VWM concentration for $\mathrm{SO}_{4}{ }^{2-}$ and $\mathrm{NO}_{3}{ }^{-}=41.2$ and
$21.6 \mu$ eq $1^{-1}$, respectively; Avila and Rodà, 2002). In northeastern Spain, calcium carbonate can be incorporated into the atmosphere from local edaphic, urban and industrial sources, but wet deposition of African dust is very important, providing on average $46 \%$ of annual Ca deposition (Avila, 1996).

Annual mean concentrations of inorganic $\mathrm{N}$ in rainwater were moderate, those of $\mathrm{NH}_{4}^{+}$being slightly higher than $\mathrm{NO}_{3}^{-}$(Table 2). As expected, $\mathrm{NH}_{4}^{+}$concentrations were higher at PA, the lowland site closer to cultivated fields and farms with animals (Table 2). At PA, the comparison of bulk and wet collecting methods showed very small differences statistically (paired $t$-test) non-significant for all major elements, except for $\mathrm{NH}_{4}^{+}$which was $5 \%$ higher in wet collectors (Table 2).

Averaging over the period 1983-2000, the $\mathrm{N}$ inputs in bulk deposition at La Castanya were $2.9 \mathrm{~kg} \mathrm{ha}^{-1} \mathrm{yr}^{-1}$ for $\mathrm{NH}_{4}^{+}-\mathrm{N}$ and $2.7 \mathrm{~kg} \mathrm{ha}^{-1} \mathrm{yr}^{-1}$ for $\mathrm{NO}_{3}^{-}-\mathrm{N}$ resulting in a wet input of $5.6 \mathrm{~kg} \mathrm{~N} \mathrm{ha}^{-1} \mathrm{yr}^{-1}$. Forest canopies are very effective surfaces for dry deposition, but dry deposition fluxes are difficult to measure and dry inputs are not often taken into account. For N, various studies in north-American deciduous forests have shown the predominant role of deposition of $\mathrm{HNO}_{3}$ vapour and coarse nitrate aerosols which produce a dry input flux that can be even higher than that of wet $\mathrm{N}$ deposition (Lovett and Lindberg, 1986, 1993).

Dry deposition of $\mathrm{NO}_{3}^{-}-\mathrm{N}$ and $\mathrm{NH}_{4}^{+}-\mathrm{N}$ at La Castanya was higher on branches than on metacrylate plates, probably because the foliage is more efficient in capturing airborne substances than horizontal plates due to differences in both the surface area of catch and the degree of air turbulance. Therefore, it was considered that branch washes gave a better estimate of dry-deposited $\mathrm{N}$ than metacrylate plates (Rodrigo and Avila, 2002). The fluxes estimated from washing branches amounted to $9.2 \mathrm{~kg} \mathrm{ha}^{-1} \mathrm{yr}^{-1}$, about $60 \%$ higher

Table 2. Volume-weighted mean concentrations in bulk or wet-only precipitation and deposition of inorganic $\mathrm{N}$ at Montseny at two study sites: La Castanya (LC) and Santa Maria de Palautordera (PA).

\begin{tabular}{|c|c|c|c|c|c|c|}
\hline \multirow[t]{2}{*}{ Site } & \multirow{2}{*}{$\begin{array}{l}\text { Length of } \\
\text { study period } \\
(y r)\end{array}$} & \multirow[t]{2}{*}{$\begin{array}{l}\text { Precipitation } \\
\left(m m y r^{-1}\right)\end{array}$} & \multicolumn{2}{|c|}{$\begin{array}{l}\text { Concentration } \\
\left(\mu e q l^{-1}\right)\end{array}$} & \multicolumn{2}{|c|}{$\begin{array}{l}\text { Deposition } \\
\left(k g N h a^{-1} y r^{-1}\right)\end{array}$} \\
\hline & & & $\mathrm{NH}_{4}^{+}$ & $\mathrm{NO}_{3}^{-}$ & $\mathrm{NH}_{4}-\mathrm{N}$ & $\mathrm{NO}_{3}-\mathrm{N}$ \\
\hline LC, bulk & $17^{\mathrm{a}}$ & 901 & 22.8 & 21.6 & 2.88 & 2.73 \\
\hline PA, bulk & $4^{b}$ & 740 & 44.7 & 32.4 & 4.63 & 3.36 \\
\hline PA, wet & $4^{b}$ & 705 & 47.0 & 31.7 & 4.64 & 3.13 \\
\hline
\end{tabular}

\footnotetext{
a From January 1983 to September 2000

From June 1995 to June 1999.
} 
than the estimated bulk deposition flux. The total deposition flux of inorganic $\mathrm{N}$ was estimated as $14.8 \mathrm{~kg} \mathrm{ha}^{-1} \mathrm{yr}^{-1}$. The same methodology was used at a nearby holm oak site Riera de Sant Pere $(7 \mathrm{~km}$ linear distance from La Castanya and $1.5 \mathrm{~km}$ from PA, 530 m.a.s.1.) with a higher exposure to traffic and industrial pollution. At this site, total $\mathrm{N}$ deposition was estimated to be $21.9 \mathrm{~kg} \mathrm{ha}^{-1} \mathrm{yr}^{-1}$, with $67 \%$ of the total $\mathrm{N}$ amount being as dry deposition (Rodà et al., 2002). For the forests within the Integrated Forest Study in eastern United States, $\mathrm{N}$ dry deposition $\left(\mathrm{HNO}_{3}\right.$, and $\mathrm{NO}_{3}{ }^{-}$and $\mathrm{NH}_{4}{ }^{+}$ in fine and coarse particles) ranged between $39 \%$ to $59 \%$ of total deposition, and total $\mathrm{N}$ deposition varied between 4.7 and $27 \mathrm{~kg} \mathrm{ha}^{-1} \mathrm{yr}^{-1}$ (Lovett and Lindberg, 1993).

At sites with moderate $\mathrm{N}$ inputs, canopies intercept and retain much of the incident $\mathrm{N}$ input fluxes because of stomatal or cuticular uptake or retention by philosphere organisms (Parker, 1983; Pucket, 1990; Lovett and Lindberg, 1993). That was the case at La Castanya: net throughfall fluxes for $\mathrm{NO}_{3}{ }^{-} \mathrm{N}$ and $\mathrm{NH}_{4}{ }^{+}-\mathrm{N}$ were negative indicating net retention at the canopy level despite the nonnegligible total deposition fluxes. On the other hand, at the more pollutant-exposed site of RP, net throughfall fluxes shifted to positive, although very small, values ( 0.3 and 1.2 $\mathrm{kg} \mathrm{ha}^{-1} \mathrm{yr}^{-1}$ for $\mathrm{NO}_{3}^{-}$and $\mathrm{NH}_{4}^{+}$respectively).

\section{Nitrogen leaching}

The changes in the chemistry as water crosses the ecosystem are shown in Fig. 1. To highlight the changes for $\mathrm{N}$ compounds, the changes in their concentrations are displayed in Table 3. At La Castanya, concentrations of $\mathrm{NO}_{3}^{-}$ and $\mathrm{NH}_{4}^{+}$in throughfall were similar to those in rainwater, throughfall fluxes being lower (and hence net fluxes negative) due to a $20 \%$ water interception at the canopy

Table 3. Water chemistry profile for $\mathrm{NH}_{4}^{+}$and $\mathrm{NO}_{3}^{-}$at $\mathrm{La}$ Castanya (Montseny)

\begin{tabular}{|c|c|c|c|}
\hline Variable & $\begin{array}{l}\text { Water } \\
\text { flux } \\
m m y r^{-1}\end{array}$ & $\begin{array}{l}\mathrm{NH}_{4}^{+} \\
\mu e q l^{-1}\end{array}$ & $\begin{array}{l}\mathrm{NO}_{3}^{-} \\
\mu e q l^{-1}\end{array}$ \\
\hline Bulk Precipitation & $891^{\mathrm{a}}$ & 22.8 & 21.6 \\
\hline Throughfall & $565^{\mathrm{b}}$ & 27.1 & 22.4 \\
\hline Forest Floor Throughflow & - & 7.0 & 249 \\
\hline Soil Solution & - & $<2$ & 4.0 \\
\hline Deep Flow & - & $<2$ & 40.0 \\
\hline Streamwater & $311^{a}$ & $<2$ & 1.3 \\
\hline
\end{tabular}
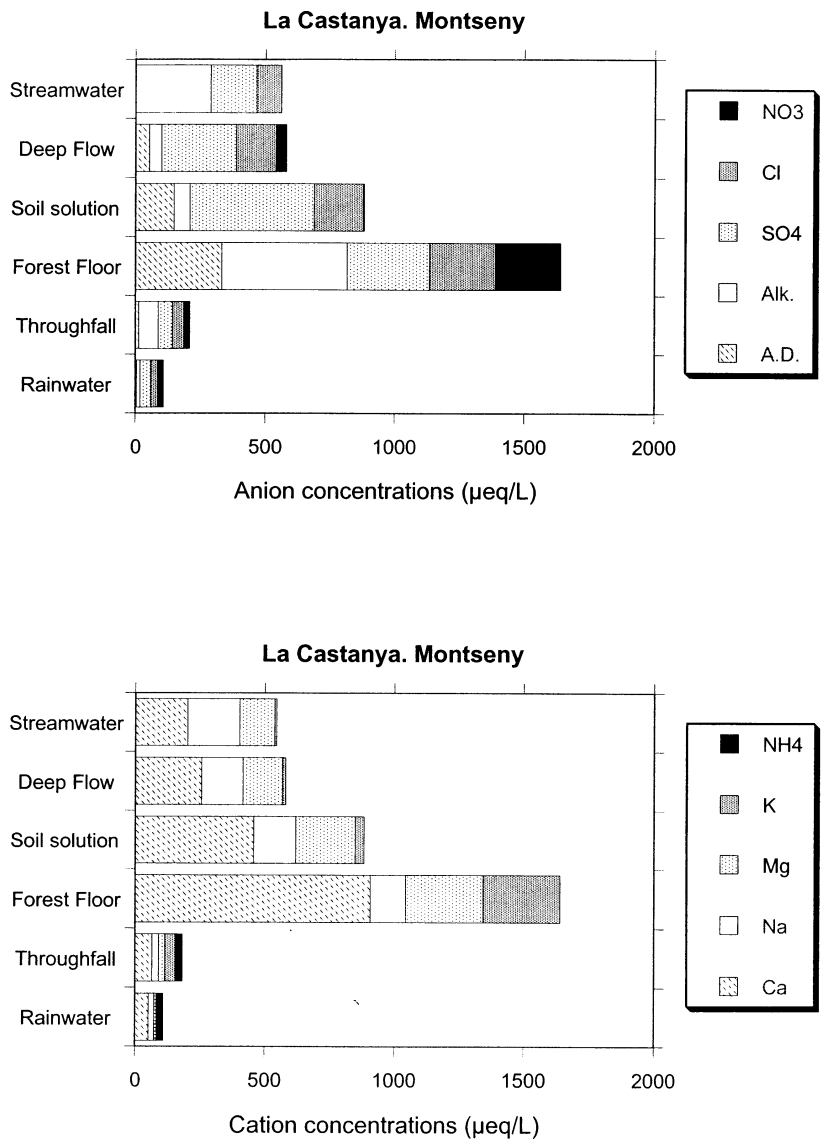

Fig 1. Water chemistry profiles for the holm oak forest at La Castanya (Montseny). a) anions, b) cations. A.D = anion deficit (sum of cations - sum of anions).

(Rodrigo, 1998). At the forest floor, mean volume-weighted $\mathrm{NO}_{3}^{-}$was $250 \mu \mathrm{eq} \mathrm{l}^{-1}$, while $\mathrm{NH}_{4}^{+}$concentration was only $7 \mu$ eq $1^{-1}$. Despite the low $\mathrm{NH}_{4}^{+}$concentration, H-layer throughflow was the only sampled soil water type that consistently showed detectable $\mathrm{NH}_{4}^{+}$.

Changes occurring along the profile across the ecosystem indicate a decreasing trend in inorganic $\mathrm{N}$ concentrations, although the pattern is different for the two forms of $\mathrm{N}$. Ammonium disappeared when water entered the soil at the forest floor level never to be detected again, either in the soil solution or in the streamwater. For $\mathrm{NO}_{3}^{-}$, maximum concentrations were found at the forest floor level, decreased to $4 \mu \mathrm{eq} \mathrm{l}^{-1}$ in soil solution and increased again in the deep subsurface flow to $40 \mu \mathrm{eq} \mathrm{l}^{-1}$ (Fig. 1). The high $\mathrm{NO}_{3}^{-}$ concentrations in the $\mathrm{H}$ layer throughflow can result from combined biogeochemical processes affecting the canopy and the forest floor, such as throughfall quantity and chemistry, and the amount of solutes released during organic matter mineralisation and nitrification. The highest $\mathrm{NO}_{3}^{-}$ concentrations in the $\mathrm{H}$ horizon correspond with the site in the soil profile of highest nitrification rates (Serrasolses et 
al., 1999). In the soil solution, $\mathrm{NO}_{3}^{-}$and $\mathrm{NH}_{4}^{+}$concentrations decreased, probably due to plant uptake and microbial immobilization. Deep through-flow presented intermediate $\mathrm{NO}_{3}^{-}$concentrations between the water collected below the forest floor and that collected from tension lysimeters at 20 and $40 \mathrm{~cm}$ depth. This indicates that free flowing water at the contact with the bedrock is a mixture of macropore water flowing from the forest floor and pre-event displaced soil solution from the mineral soil (Avila et al., 1995). The behaviour of other ions and, in particular, that of ionic ratios to $\mathrm{Cl}^{-}$taken as a tracer scarcely affected by exchange processes or biological uptake, gives support to this interpretation (Melià et al., 1999).

The inorganic $\mathrm{N}$ concentrations in streamwater were very low: as mentioned for $\mathrm{NH}_{4}^{+}$, they were always under the analytical detection limit. For $\mathrm{NO}_{3}^{-}$, the same applied for baseflow samples. However, $\mathrm{NO}_{3}^{-}$concentrations increased during high flows. Nitrate concentration maxima usually occurred in advance of peak flow; therefore, $\mathrm{NO}_{3}{ }^{-}$presented usually clockwise hysteretic loops when plotted against discharge (Avila, 1988). Such behaviour can result either

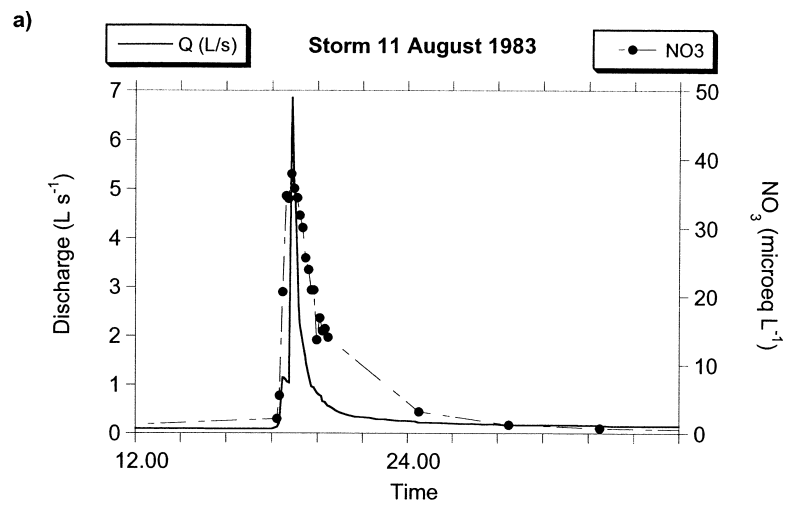

b)

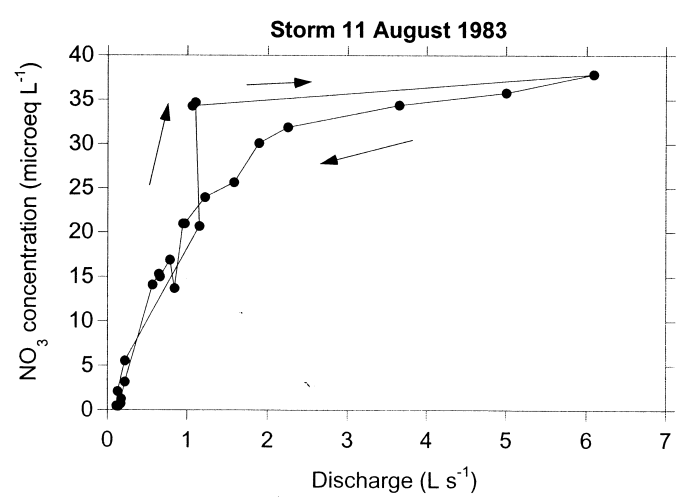

Fig 2. Dry antecedent conditions event in 11 August 1983. a) Hydrograph and variation of $\mathrm{NO}_{3}^{-}$concentrations in TM9 streamwaters, and b) $\mathrm{NO}_{3}^{-}$hysteresis with discharge. from an initial flushing of a limited ion supply, or from changing the proportional contribution of different flowpaths during the events.

A distinction has to be made between two types of hydrograph responses: those corresponding to dry antecedent conditions and those to wet antecedent conditions. Hydrograph characteristics and the variation of $\mathrm{NO}_{3}^{-}$concentrations were very different between both types. An example of an event under dry antecendent conditions is depicted in Fig. 2 and with wet antecedent conditions in Fig. 3. For dry antecedent conditions, the peak flow was reached quickly and the recession returned to pre-storm levels in a scale of hours (Fig. 2). This implied small runoff, the percentage of precipitation that resulted in quick flow ranging between $0.5 \%$ and $8.7 \%$ for the different storms (Table 4). For storm flow in humid antecedent conditions, the time to reach the peak flow increased and high flow was maintained for days (Fig 3): the storm runoff was higher, and percentages of quick flow with respect to precipitation ranged between $18 \%$ and $58 \%$ for the different storm events sampled (Table 4).

a)

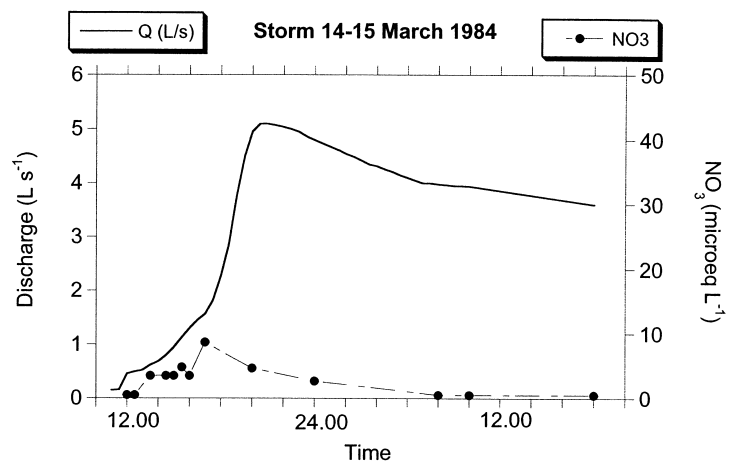

b)

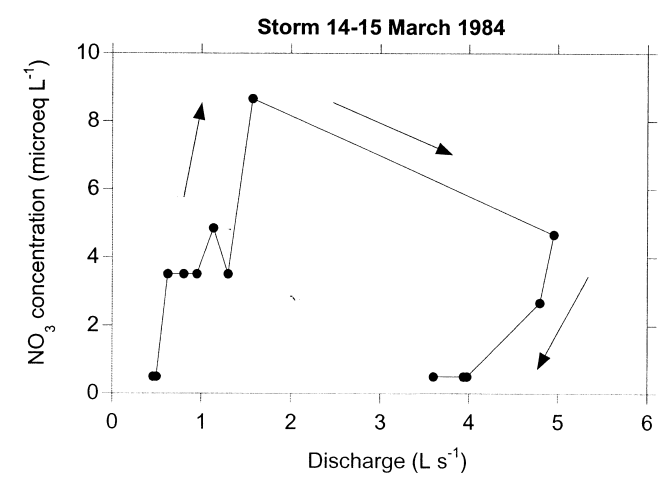

Fig 3. Wet antecedent conditions event in 14-15 March 1984. a) Hydrograph and variation of $\mathrm{NO}_{3}^{-}$concentrations in TM9 streamwaters, and b) $\mathrm{NO}_{3}^{-}$hysteresis with discharge. 


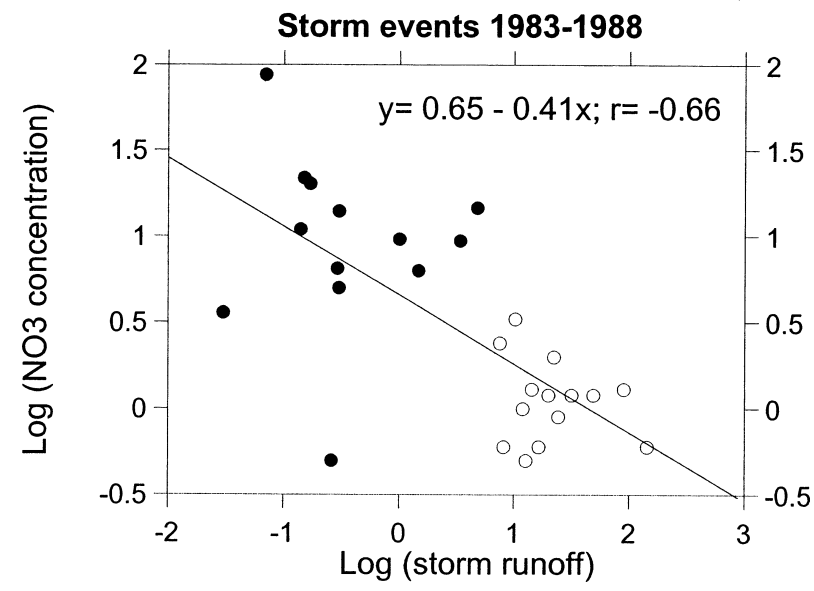

Fig 4. Log-log relationship between storm flow volume-weighted mean $\mathrm{NO}_{3}^{-}$concentration and storm runoff. Storms are distinguished according to the humidity antecedent conditions at the TM9 catchment (La Castanya, Montseny). Filled dots correspond to storms with dry antecedent conditions; blank dots correspond to stroms with wet antecedent conditions.

Table 4. Hydrograph characteristics for stormflows separated according to humidity antecedent conditions at the TM9 catchment in La Castanya valley (Montseny). Arithmetic means (in brackets, standard error) are given for the storms recorded from August 1983 to July 1988.

\begin{tabular}{lllll}
\hline Variable & $\begin{array}{l}\text { Dry } \\
\text { antecedent } \\
\text { conditions } \\
\mathrm{n}=13\end{array}$ & $\begin{array}{l}\text { Wet } \\
\text { antecedent } \\
\text { conditions } \\
\mathrm{n}=14\end{array}$ \\
\hline Peakflow $\left(1 \mathrm{~s} \mathrm{~s}^{-1} \mathrm{~km}^{-1}\right)$ & $54.2(17.0)$ & 137.8 & $(42.2)$ \\
Runoff $\left(\mathrm{mm}^{2}\right)$ & $0.95(0.41)$ & 30.7 & $(9.52)$ \\
Runoff/rainfall & $0.02(0.006)$ & 0.44 & $(0.06)$ \\
Time to peakflow (hour) & $4.96(2.18)$ & 53.5 & $(113)$ \\
\hline
\end{tabular}

Solute behaviour mirrored these differences in hydrological response. The changes in $\mathrm{NO}_{3}{ }^{-}$concentrations reflected the various water pathways through the ecosystem compartments and the different water residence times. In stormflow associated with dry antecedent conditions, $\mathrm{NO}_{3}^{-}$ reached brief peaks of high concentration at or near the peak of flow (Fig. 2), probably because of the contribution of Hortonian partial overland flow with the chemical characteristics of the $\mathrm{H}$ layer forest floor (Table 3). In wet antecedent conditions, a dominant contribution of subsurface flow (with chemical characteristics of soil water, or deep flow, Table 3) would attest to the lower concentrations during these storm events (Fig. 3). Corresponding with these differences in water pathways and solute content, when representing, for each storm event, the volume-weighted mean $\mathrm{NO}_{3}^{-}$concentration against the storm runoff, an inverse log-log relationship appeared (Fig. 4). Storms occurring with dry antecedent conditions presented low storm runoff and high volume-weighted mean $\mathrm{NO}_{3}^{-}$ concentrations. Storms in wet antecedent conditions produced higher drainage but, because of subsurface major pathways, they had very low volume-weighted mean $\mathrm{NO}_{3}^{-}$ concentrations.

At baseflow, with groundwater as the major component of streamflow, $\mathrm{NO}_{3}{ }^{-}$concentrations were very low throughout the year. This contrasted with the seasonality reported for other Mediterranean streams in Catalonian forests (Butturini and Sabater, this issue) and for northern deciduous forest ecosystems, with higher $\mathrm{NO}_{3}^{-}$levels during the inactive winter season (Likens and Bormann, 1995). The fact that at La Castanya $\mathrm{NO}_{3}{ }^{-}$showed high concentrations $\left(>50 \mu \mathrm{eq} \mathrm{l}^{-1}\right.$ ) only during very short times at peak flows of dry antecedent conditions testifies to the tight $\mathrm{N}$ cycle in this holm oak undisturbed ecosystem. Averaged over 10 years (1984-1994), the export of $\mathrm{N}$ at the catchment outlet was only $0.05 \mathrm{~kg} \mathrm{~N} \mathrm{ha}^{-1} \mathrm{yr}^{-1}$, a low figure when compared to the export at Riera Major $\left(0.66 \mathrm{~kg} \mathrm{~N} \mathrm{ha}^{-1} \mathrm{yr}^{-1}\right.$, Butturini and Sabater, 2002) a stream draining similar holm oak forests but with N-fixing Alnus glutionosa on the streamsides.

Biological demand for $\mathrm{N}$ is a major process for the tightly closed $\mathrm{N}$ cycle at La Castanya forest. This was demonstrated by a root-trenching experiment where water and nutrient uptake by tree roots was prevented by building trenched plots. Six months after trenching, $\mathrm{NO}_{3}^{-}$in the soil solution increased to concentrations between 2000 and $2500 \mu$ eq $1^{-1}$ (Bonilla and Rodà, 1990), while at the control plots, $\mathrm{NO}_{3}^{-}$ concentration remained around $10 \mu \mathrm{eq} \mathrm{l}^{-1}$.

In a comparative study of $\mathrm{N}$ budgets for 65 forested catchments and plots in North and Central Europe submitted to a wide range of total $\mathrm{N}$ deposition, Dise and Wright (1995) proposed a $\mathrm{N}$ deposition threshold of $10 \mathrm{~kg} \mathrm{~N} \mathrm{ha}^{-1} \mathrm{yr}^{-1}$ in throughfall fluxes; thereafter significant $\mathrm{NO}_{3}^{-}$leaching would start to occur from forests. The present study at the holm oak forest of La Castanya indicates that, although the estimated total $\mathrm{N}$ input is not negligible, canopy processes and biological uptake retain most of the input within the ecosystem.

\section{Conclusion}

Biological demand is a major controlling process for a tight $\mathrm{N}$ cycle at the holm oak forest of La Castanya (Montseny). The atmospherically deposited $\mathrm{N}$ is almost completely retained within the ecosystem, possibly because holm oak 
forests at Montseny were harvested until around 1950 and are now in an aggrading phase. In contrast, high $\mathrm{N}$ deposition poses a problem of excess $\mathrm{N}$ in soils and streamwaters at more mature forests in North America or central and North Europe subjected over many years to high $\mathrm{N}$ loads.

\section{Acknowledgements}

This research has been funded by CAICYT (2129/83), CICYT (AMB-0349, HYD-0581), McyT (REN-0659/CLI) and the European projects ENCORE and DM2E. The collaboration of the Departament de Medi Ambient de la Generalitat de Catalunya is fully acknowledged. The research has benefited from laboratory and field support from CREAF personnel.

\section{References}

Aber, J.D., Nadelhoffer, K.J., Steudler, P. and Melillo, J.M., 1989. Nitrogen saturation in northern forest ecosystems. BioSci., 39, 378-386.

Aber, J.D., McDowell, W., Nadelhoffer, K., Magill, A., Berntson, G., Kamakea, M., McNulty, S., Currie, W., Rustad, L. and Fernandez, I., 1998. Nitrogen saturation in temperate forest ecosystems. BioSci., 48, 921-934.

Agren, G.I. and Bosatta, E., 1988. Nitrogen saturation of terrestrial ecosystems. Environ. Pollut., 54, 185-198.

Andersen, H.V., Hovmand, M.F., Hummelshoj, P. and Jensen, N.O., 1993. Measurement of ammonia flux to a spruce stand in Denmark. Atmos. Environ., 27, 189-202.

Avila, A., 1988. Balanç d'aigua i nutrients en una conca d'alzinar del Montseny. Estudis i Monografies, 13. Diputació de Barcelona. Barcelona. 219 pp.

Avila, A., 1996. Time trends in the precipitation chemistry at a montane site in north-eastern Spain for the period 1983-1994. Atmos. Environ., 30, 1363-1373.

Avila, A., Bonilla, D., Rodà, F., Piñol, J. and Neal, C., 1995. Soilwater chemistry in a holm oak (Quercus ilex) forest: inferences on biogeochemical processes for a montaneMediterranean area. J. Hydrol., 166, 15-35.

Avila, A. and Rodà F., 2002. Assessing decadal changes in rainwater alkalinity at a rural Mediterranean site in the Montseny Mountains (NE Spain). Atmospheric Environment, 36, 28812890.

Bonilla, D. and Rodà, F., 1990. Nitrogen cycling responses to disturbance: trenching experiments in an evegreen oak forest. In : Nutrient cycling in terrestrial ecosystems. A.F. Harrison, P. Ineson and O.W. Heal (Eds.) Elsevier, London, 179-189.

Butturini, A. and Sabater, F. 2002. Nitogen concentrations in a small Mediterranen stream: I. Nitrate. II. AmmoniumHydrol. Earth Syst. Sci., 539-550.

Bytnerowicz, A. and Fenn, M.E., 1996. Nitrogen deposition in California forests: a review. Environ. Pollut., 92, 127-146.

Dise, N. B. and Wright, R. F., 1995. Nitrogen leaching from European forests in relation to nitrogen deposition. Forest Ecol. Manage., 71, 153-161.

Emmett, B.A., Reynolds, B., Stevens, P.A., Norris, D.A., Hughes, S., Görres, J. and Lubrecht, I., 1993. Nitrate leaching from afforested Welsh catchment: interaction between stand age and nitrogen deposition. Ambio. 22, 386-394.

EMEP 2000 from http://www.emep.int/
Fenn, M.E., Poth, M.A. and Johnson, D.W., 1996. Evidence for nitrogen saturation in the San Bernardino mountains in southern California. Forest Ecol. Manage., 82, 211-230.

Galloway, J.N., 1995. Acid deposition: perspectives in time and space. Water Air Soil Pollut., 85, 15-24.

Likens, G.E. and Bormann, F.H., 1995. Biogeochemistry of a forested ecosystem. 2nd Edition. Springer Verlag. New York. $159 \mathrm{pp}$.

Lovett, G.M. and Lindberg, S.E., 1986. Dry deposition of nitrate to a deciduous forest. Biogeochem., 2, 137-148.

Lovett, G.M. and Lindberg, S.E., 1993. Atmospheric deposition and canopy interactions of nitrogen in forests. Can. J. Forest Res., 23, 1603-1616.

Melià, N., Bellot, J. and Vallejo, V.R., 1999. Soil water chemistry. In: Ecology of Mediterranean Evergreen Oak Forests. F. Rodà, J. Retana, C. Gracia, and J. Bellot (Eds.). Springer, Berlin, 237-251.

Mosello, R., Bianchi, M., Geiss, H., Marchetto, A., Morselli, L., Muntau, H., Tartari, G.A., Serrini, G. and Serrini Lanza, G., 1998. Italian Network for the Chemistry of Atmospheric Deposition. Intercomparison 1/98. Consiglio Nazionale delle Ricerche. Istituto Italiano di Idrobiologia. Verbania Pallanza. $81 \mathrm{pp}$.

Nihlgard, B., 1985. The ammonium hypothesis- An additional explanation for the forest dieback in Europe. Ambio, 14, 2-8.

Parker, G.G., 1983. Throughfall and stemflow in the forest nutrient cycle. Adv. Ecol. Res., 13, 57-133.

Pucket, L.J. 1990. Estimates of ion sources in deciduous and coniferous throughfall.. Atmos. Environ., 24, 545-555.

Rodà, F., Avila, A. and Rodrigo, A., in press. Nitrogen deposition in Mediterranean forests. Environ. Pollut.

Rodrigo, A., 1998. Deposició atmosfèrica en dos alzinars (Quercus ilex) del Montseny sotmesos a una exposició contrastada de contaminants de l'àrea barcelonina i vallesana. $\mathrm{Ph}$ Dissertation. Universitat Autònoma de Barcelona. 330 pp.

Rodrigo, A. and Avila, A., 2002. Dry depositon to the forest canopy and surrogate surfaces in two Mediterranean holm oak forests in Montseny (N E Spain). Water Air Soil Pollut., 136, 269 288.

Sabaté, S., Sala, A. and Gracia, C.A., 1999. Leaf traits and canopy organization. In: Ecology of Mediterranean Evergreen Oak Forests. F. Rodà, J. Retana, C. Gracia, and J. Bellot (Eds.). Springer, Berlin, 121-133.

Serrasolses, I., Diego, V. and Bonilla, D., 1999. Soil nitrogen dynamics. In: . Ecology of Mediterranean Evergreen Oak Forests. F. Rodà, J. Retana, C. Gracia, and J. Bellot (Eds.). Springer, Berlin, 223-235.

Van Breemen, N., Mulder, J. and Van Grinsven, J.J.M., 1987. Impacts of acid atmospheric deposition on woodland soils in the Netherlands. II. Nitrogen transformations. Soil Sci. Amer. J., 51, 1634-1640.

Vitousek, P.M., 1977. The regulation of element concentration in mountain streams in the northeastern United States. Ecol. Monogr., 47, 65-87.

Vitousek, P. M., Aber, J.D., Howarth, R.W., Likens, G.E., Matson, P.A., Schindler, D.W., Schlesinger, W.H. and Tilman, D.G., 1997. Human alteration of the global nitrogen cycle: sources and consequences. Ecol. Appl., 7, 737-750.

Wyears, G.P., Vermuelen, A.T. and Slanina, J., 1992. Measurement of dry deposition of ammonia on a forest. Environ. Pollut., 75, 25-28. 
